\title{
The Social Value of Elephant Tusks and Bronze Drums among Certain Societies in Eastern Indonesia
}

\author{
Leonard Yuzon Andaya \\ University of Hawai'i, Manoa \\ andaya@hawaii.edu
}

\begin{abstract}
This study seeks to explain how and why elephant tusks and bronze kettledrums came to occupy such an important social and ritual position in certain societies in eastern Indonesia. It argues that these two objects were selected because they came to be associated with ideas of authority and rain/fertility. In making this claim, this study suggests that the ideas and symbolism associated with elephants and bronze drums in both India and Southeast Asia found relevance in, and were thus adopted by, specific societies in eastern Indonesia. Contemporary Dutch East India Company accounts and local traditions provide evidence of the role of the Javanese kingdom of Majapahit and the Makassarese kingdom of Gowa as the principal transmitters of these ideas through an extensive international trade in the highly coveted spices of eastern Indonesia.
\end{abstract}

\section{Keywords}

elephant tusk - bronze drums - bridewealth - trade - eastern Indonesia - fertility

\section{Introduction}

Ivory and bronze kettledrums as trade commodities can be traced far back in time to very early civilizations. The ivory was mainly carved into bangles, but it was also used to create works of religious devotion or an artistic tour de force that would gain the praise of a patron. Rarely was a whole tusk preserved uncarved, and on the few occasions when this occurred the intention was usu-

(C) LEONARD YUZON ANDAYA, 2016 DOI: 10.1163/22134379-17201001

This is an open access article distributed under the terms of the Creative Commons 
ally to retain the memory of a great royal elephant (Gröner and Saller 1998; Ringis 1996:124). The bronze kettledrums in various sizes and forms are another 'commodity' that has ancient origins, and can be found dispersed throughout southern China and Southeast Asia. While they functioned as musical instruments in some communities, in others they were mainly preserved as precious objects to be displayed on auspicious occasions.

In the eastern Indonesian islands known as Nusa Tenggara Timur (Eastern Lesser Sundas) and in southern Maluku there are certain societies that greatly value the uncarved elephant tusk and/or the bronze drums as essential to bridewealth. Elephants are not found in these islands, and bronze drums are a rarity, yet the practice of requiring these items as bridewealth has continued in some quarters to the present day. The replenishing of supplies of elephant tusks did not pose too much of a problem until very recent times, but bronze drums were far rarer and difficult to obtain. Yet among a few communities in eastern Indonesia, where these drums are vital for the preservation of social relationships, a solution was found in eastern Java, where the cheaper brass drums were manufactured precisely for this market.

This article, then, seeks to explain how and why elephant tusks and bronze kettledrums came to occupy such an important social and ritual position in these particular societies in eastern Indonesia. It is my contention that these two objects were selected because they came to be associated with ideas of authority and rain/fertility. To reach this conclusion, I have sought to explain the role that elephants and bronze drums played in both India and Southeast Asia, and to suggest that the symbolism associated with these objects in those regions would have been absorbed by certain eastern Indonesian societies based on their use of one or both of these specific objects as representations of elite status and authority and as a symbol of fertility. The means by which such ideas were transmitted over long distances and considerable time periods was an ancient international trade route stretching from the Middle East and India through Southeast Asia and then on to China. This trade involved eastern Indonesia's highly coveted spices (cloves, nutmeg, mace), aromatic woods (cinnamon, sandalwood), and sea products (tortoiseshell, tripang, or bêche-de-mer) (Andaya 2011). Exchange of cultural and technological ideas through ongoing commercial contact is well documented in history, and it was this mode of interaction that I believe was responsible for this transfer of some of the symbolism of elephants and bronze kettledrums to eastern Indonesia. 


\section{Transmission of Ideas to Eastern Indonesia through Trade}

In the first 1500 years of the Common Era (CE), the stimulus of trade in eastern Indonesian spices contributed to the rise and prosperity of kingdoms along the major spice routes. The primary redistribution centres in Southeast Asia for the spices were Srivijaya (c. seventh to eleventh century CE) in southeast Sumatra and its successor, Melaka (c. 1400-1511 CE), along the Straits of Melaka; the eastern Javanese kingdom of Majapahit (late thirteenth to early sixteenth century CE); and the Makassarese twin kingdoms of Gowa-Tallo (sixteenth to eighteenth century $\mathrm{CE}$ ) in the southwest peninsula of Sulawesi. Until the destruction of the Banda islands by the Dutch in the early seventeenth century, the Bandanese were the main shippers of spices to these redistribution centres, bringing cargoes of cloves from northern Maluku and nutmeg and mace from their own forests. One of the scheduled stops along this trade route was Bantaeng, on the southern coast of the island of Sulawesi, just opposite the nearby island of Salayar (Bougas 1998:93). The sources from Srivijaya are mainly silent on this particular trade, though Arab traders and Chinese pilgrims have provided glimpses of the prosperity of that kingdom, some or most of it due to the spice trade. Srivijaya was a Mahayana Buddhist kingdom, and 'Indianized'1 ideas of kingship and religion would have circulated along with the trade being transacted in its ports. A similar scenario can be applied to the later kingdom of Melaka, though its conversion to Islam around the 153 os began the Islamization of the society at the expense of some of the Indianized ideas (Andaya 2008; Wolters 1970, 1967).

The most direct transmission of Indianized ideas to eastern Indonesia was via Majapahit and the Makassarese twin kingdoms of Gowa-Tallo. While early Indianization in the first millennium CE may have accounted for some of the transfer of ideas, one of the first and most important conduits of such views was the eastern Javanese kingdom of Majapahit, a major Hindu-Buddhist civilization that extended its influence to the east as far as the coasts of western New Guinea. The Desawarnana, a Javanese court text written by the Majapahit poet Mpu Prapanca in 1365, lists 'islands and all the surrounding countries which seek refuge' in Majapahit. Among the places listed that are directly relevant to this study are Sumbawa and Bima (on Sumbawa Island), Bantaeng, Salayar, and Makassar (in southwest Sulawesi), Galiyao (Alor and Pantar), Solor,

1 I prefer to use the word 'Indianized' rather than 'Indian' to refer to this process, because Indian concepts were localized or adapted by the receiving societies while retaining their Indian essence. 


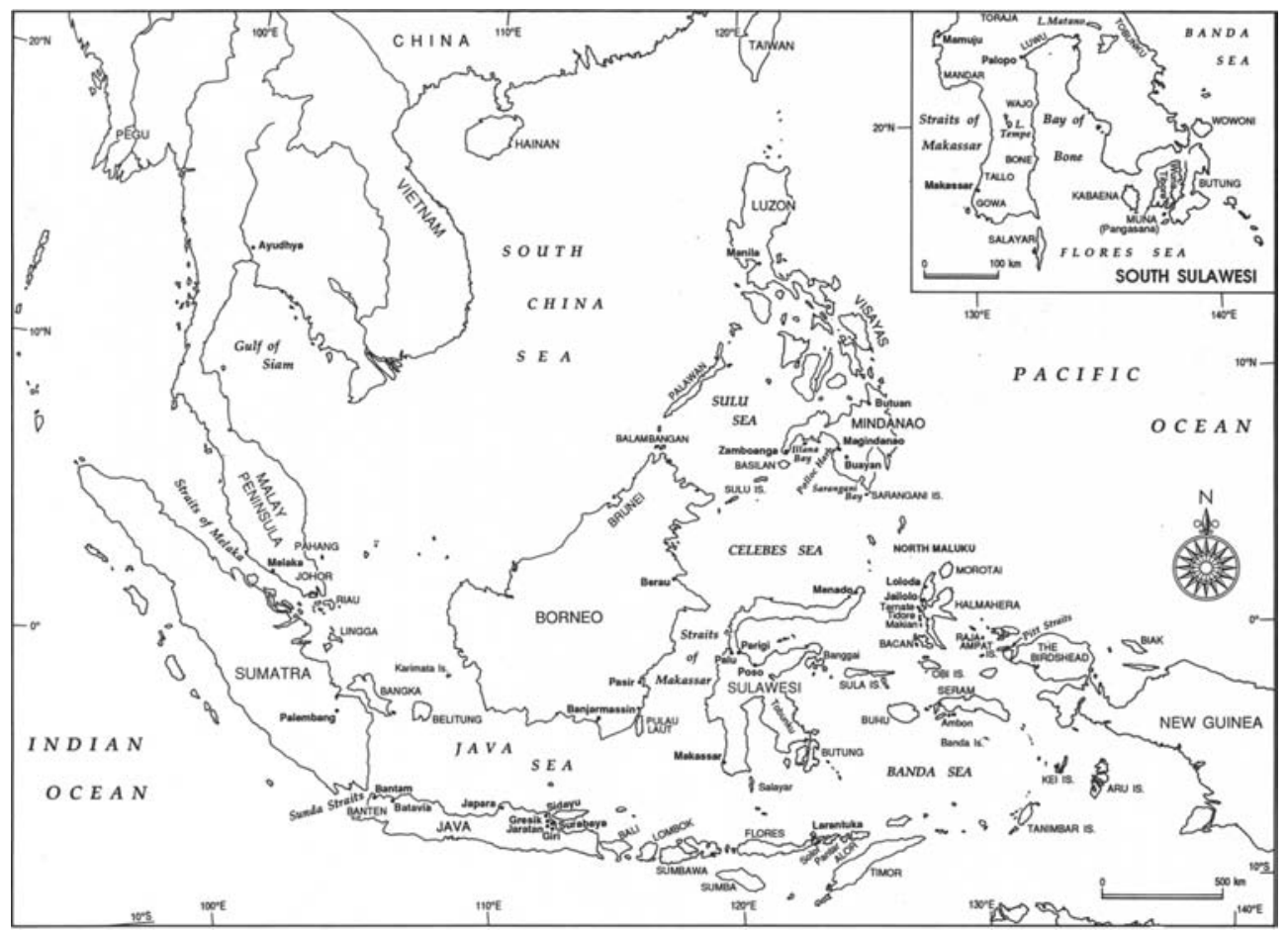

FIGURE 1 The island world of Southeast Asia

Seram, Timor, Banda, Ambon, Maluku, and Onin (in Papua) (Robson 1995:334). Most scholars agree that the relationship was mainly an economic one, though the cultural influence of Majapahit is also mentioned in local traditions. There are legends in these islands that tell of Javanese who fled to the east after the fall of Majapahit and acquired responsible positions among communities of lower technological development, such as those on Flores, Alor, Pantar, Sawu, and other islands (Hägerdal 2012:25fn21). In the Solor archipelago are tales that attribute to Majapahit the establishment of clans and other traditions (Gomang 1993:30, 69, 87; Widiyatmika, Suratha and Frans 1978:19). Other eastern Indonesian societies also possess traditions that link certain spiritually powerful objects or practices to this almost legendary Javanese kingdom. It is noteworthy that in the whole of western Indonesia, the unique category of eastern Indonesian kettledrums (which Amba Calò has categorized as Region Specific Cluster 3, or RS3), is only found in eastern Java between Tuban and Gresik (Calò 2009:111), two principal ports of the kingdom of Majapahit through which the spice trade to eastern Indonesia was conducted (Andaya 2011:112). 
The most important later source of Indianized ideas that travelled to eastern Indonesia were the twin Makassarese kingdoms of Gowa-Tallo. The southwest peninsula of Sulawesi has ancient archaeological sites that indicate long contact with the outside world (Bellwood 1985). The extensive trade connections with the western archipelago would have facilitated the flow of Indianized ideas to southwest Sulawesi and further eastward. Even the traditions of the second coming of god-rulers to Sulawesi are often dated to about the time of Majapahit's rise to power (Pelras 1996:49-50; Bulbeck and Caldwell 2000:1067). While Gowa focused initially on agriculture and land, Tallo's orientation was towards the sea and trade. Tallo's successful maritime commerce is conveyed in the Tallo chronicles, in which the details are related of a critical marriage between a Tallo prince and a princess from Siang, the predecessor of Gowa-Tallo as the leading entrepôt in southwest Sulawesi. The son born of this marriage then takes a Surabayan woman as his wife (Rahim and Borahima 1975:6). Surabaya was an important Majapahit port at the eastern end of Java that served the international spice trade, and so the mention of this marriage as part of the narrative of Tallo's rise may be more than coincidental. Tallo rulers were reputed to have visited their trade partners as far west as Melaka and eastward to the islands of Ende (Flores), Banda, and Nusa Tenggara (LesserSundas).

The folklore of many communities in Nusa Tenggara and central Maluku involves the incursions of the Makassarese, who forced the people to pay obeisance to the ruler of Tallo (Kolit 1982:24). Spillett (1999) has combed the local sources on Timor and catalogued the numerous instances of Makassarese influences that date back for centuries. They are mentioned as prominent players in the waters of eastern Indonesia in the voc records of the seventeenth and eighteenth centuries. As bearers of goods and concepts from abroad, the Makassarese traders would have been responsible for the ongoing flow of Indianized ideas that came initially from Majapahit, then through the Makassarese twin kingdoms of Gowa-Tallo (referred to simply as Gowa after 1535), and finally to the various islands in eastern Indonesia. Among these ideas would have been the symbolism of elephants/elephant tusks and bronze drums, which created such a strong impression that they became integrated into the political and social fabric of particular Indonesian societies. It is to this symbolism and its relationship to these societies that I will now turn.

\section{The Elephant and Its Symbolism}

India has without question one of the most extensive and complex legends and rituals in the world with regard to the elephant, and many of these beliefs 
were transmitted to Southeast Asia during the period of Indianization in the first millennium and a half of the Common Era. ${ }^{2}$ The elephant's enormous size and prodigious strength have benefitted societies that have been able to harness it as a beast of burden or as a formidable and terror-inducing weapon in warfare. Under the Mughals in sixteenth- and seventeenth-century India, elephant units constituted the core of the emperor's army. In Siam, too, a French envoy to the Siamese court in 1687 observed that elephants formed the principal force in the Siamese army and were therefore highly esteemed. Great prestige was attached to the high official in charge of their care, which was 'one of the greatest employments of the kingdom'. Some Siamese claimed that the ruler had some 10,00o elephants, and that at least three men were entrusted to the care of a single elephant (De la Loubère 1986:89).

The elephant was associated with the power and majesty of rulers. In the Indian Vedas the elephant is depicted as a symbol of royal power, and one scholar even asserts that Indra, the chief god on sacred Mt Meru, the abode of the gods, 'is as it were an elephant'. It is an idea which was later retained in the elephant-headed god, Ganesha, and even extended to Buddhist legend, where the white elephant becomes the harbinger of the birth of the Buddha (Zimmer 1962:103). In many Indian hymns the elephant is praised as being on the level of kings, and 'thus elephants should be protected like the life of a king'. One particular legend even proclaims that 'neither of the two outshines the other, elephants are consubstantial with kings'. In early Burma no king would mount a white elephant, because it could be a reincarnation of a former ruler (Gröner and Saller 1999:134, 164).

Both in India and in Southeast Asia, rulers have sought to obtain the largest and most impressive of these animals to become part of the royal stables to serve as royal mounts and for purposes of magic (Zimmer 1962:103). During processions such magnificent beasts continue to be decorated with gold ornaments and resplendent finery to reflect the glory and power of the ruler. The most famous elephant in Indian legend, and the source of Indian reverence and worship of the animal, is Airāvata (known in Thailand as Erawan), the mount of Indra. Airāvata emerged when the universe was created from the churning of the Ocean of Milk by the demons and the gods. As a result Airāvata is depicted as a sacred white elephant, typically with four tusks in India and sometimes with five heads in Southeast Asia. When worshipped as a divine being, the white elephant is referred to as Shrī Gāja ('The Elephant of Shrì') and Megha ('Cloud'). Shrī Gāja is also known as Gāja Lakshmī ('Lakshmī

2 For a classic study of this Indianization process, see Coedès 1968 and Wolters 1999 (Chapter 1). 
of the Elephants') in reference to the two elephants who pour water over Lakshmī as the patron of fertility (Zimmer 1962:92, 105-6).

The association of Indra and the elephant is appropriate since Indra is the god of war and elephants were an important part of warfare in India and Southeast Asia. Indra is also known as the god of rain and storms, the destroyer of drought, and hence the lord that assures the abundance in the land (Ringis 1996:12-3). The elephant again plays an important supporting role as the means by which Lord Indra accomplishes this important task for the world. In one text the civil and religious officials of the kingdom are reminded to worship the white elephant so that Indra would bring rain and prosperity to the land, the people, the animals, the army, and the elephants. Neglecting this duty would invite plague, drought, and destruction (Zimmer 1962:105-9). ${ }^{3}$

The elephant is identified with rain clouds, once again reinforcing Indra's role as the bearer of rain. According to legend, elephants were once winged creatures that mated with clouds. One day some of them alighted on a tree under which a holy man was preaching. The branch broke under the weight of the elephants and fell, killing some of the pupils. So enraged was the holy man that he beseeched the gods to remove the wings from elephants, a request that was granted. But the elephants remained closely linked to clouds and, as a favour of the gods, retained the privilege of asking the clouds for rain. They thus became the intermediaries between the gods and the inhabitants of this world in bringing rain and relieving drought on earth (Gröner and Saller 1999:124). In another legend the primordial white elephant is described as 'a rain cloud walking on earth' (Ringis 1996:132). It is the association of the elephant with rain and with the god Indra, the destroyer of drought and the bestower of abundance, that has made the elephant so revered both in India and in Southeast Asia. ${ }^{4}$ In addition, the majestic beast was always identified with royal power and authority, with the white elephant a pre-eminent sign of legitimate kingship.

3 The veneration of the elephant was particularly marked among the jungle people in the Malay Peninsula. One of the badi, or elephant songs, collected from the orang asli (original people) of the Malay Peninsula in the first decade of the twentieth century is the following:

See that ye slay not the Sacred Elephant

For if you do, you will die of sacrilege

Burn ye then incense, and pay your vows to him

The Sacred Elephant loves his grandchildren in his clearings he will not forage

Nor will he forage among their coconuts (Skeat and Blagden 1906:147-8).

4 In the Sanskrit tradition in India, apparently the word for naga, or the cosmological snake associated with fertility, can also be interpreted as elephant (Vogel 1972:7n2, 63, 281). 


\section{Elephant Tusks}

While the elephant was a revered animal, why was the tusk the object of so much attention? One simple answer lies in its commercial value as the principal source of ivory for the carving of ornaments and bangles that found a ready market in many parts of the world, including India, Southeast Asia, and China. Yet it was not the carved ivory, but the whole elephant tusk that was the source of both fertility and authority. The wholeness of the tusks, one of the most prominent features of the elephant, came to represent the animal itself as a symbol of supernatural strength and power. In the Suan Pakkad Palace Museum and the Bangkok National Museum in Thailand are tusks of royal elephants which are regarded as sacred relics of the revered animal (Ringis 1996:124). As with all relics, these tusks formed a vital link between the profane and the sacred, that is, between the earthly elephants and their celestial cousins, the rain clouds, and, ultimately, to the primordial white elephant and the god Indra. This relationship becomes clear in an episode recounted in the pages of the Journal of the Siam Society in 1928 as retold in Warren 1998.

A European was travelling on an elephant through the province of Songkhla in southern Thailand when a woman suddenly appeared and spoke to the head elephant man. She then gave him a bottle of water, a brass bowl, and a candle. He took the candle, lit it, and stuck it on one corner of the brass bowl. He then gave the water bottle to the mahout sitting on the elephant's head. The mahout carefully poured the water over the elephant's head so that it would flow over the elephant's tusk. Waiting below was the elephant man, who carefully caught the water in the bowl. When the European asked for an explanation, he was told that the woman had a child sick with fever, and she intended to take this blessed water to bathe her child (Warren 1998:38). In India and Southeast Asia, a common form of worship is to pour a libation over a Siva lingam or over sacred stones, infusing the liquid with supernatural powers which then flows to the ground and provides fertility to the land. The act of pouring the water over the elephant tusk was also intended to sacralize the water and thus make it an efficacious remedy against illness.

Thailand and Burma were the two principal sources of elephant tusks. During the reign of King Narai of Siam (1656-1688), wild elephants were found in abundance in the central plains, and even in the late nineteenth century elephant herds roamed in areas only 20 to 30 miles from the capital Bangkok (Warren 1998:67, 70). But Burma outstripped all others in the supply of tusks from Ava in Upper Burma and Syriam (considered the best quality) and Pegu from Lower Burma. The Vereenigde Oost-Indische Compagnie (voc, Dutch 
East India Company) was the principal intermediary in the trade of elephant tusks, receiving an annual average of between 10,000-12,00o lbs. [4500-5500 kg] of tusks in the 1650 s, and between $15,000-20,000 \mathrm{lbs}$. [6800-900o kg] in the 1660s (Dijk 2006:70, 242). From Burma and Thailand, traders in elephant tusks often followed the traditional spice routes from the western archipelago to eastern Indonesia (Andaya 2011; Ellen 2003). In the voc sources the Dutch noted that tusks appeared regularly as trade items on local trading vessels carrying other commodities and island-hopping in the eastern Indonesian seas to Flores, the Lamaholot areas in the Solor archipelago, Tanimbar, and Aru—all lands where elephant tusks were highly prized objects as bridewealth (Noorduyn 1983:103, 109; De Roever 2002:77). ${ }^{5}$

Thus far this article has argued that the elephant was a revered animal in both India and Southeast Asia because of its association with the celestial beings and with the divine rulers on earth. Although its value was often calculated in mundane terms as a beast of burden or of war, its role as the steed of Indra, the god of war and of the rains, has more often defined the animal in the imagination of the people. Through close identification with Indra, the elephant has acquired attributes and powers of its lord, including the ability to bring rain, break a drought, and assure abundance. The tusk of this special animal is thus believed to be imbued with great spiritual power and serves as a bridge between the sacred and the profane worlds. It is this conception of elephants and their tusks as symbols of both rain/fertility and royal authority that provides the necessary framework for understanding the demand for elephant tusks in eastern Indonesia.

\section{The Social Role of Elephant Tusks in Some Societies in Eastern Indonesia}

Women, as elsewhere in the world, are valued in Southeast Asia because of their importance in reproduction. They also play a significant role in Southeast Asia in establishing and strengthening alliances with other influential families or groups through marriage, being milk-mothers to children from an allied family, and by becoming foster parents through adoption or religious ceremonies (Andaya 2006). Among the Lamaholot in the islands of Solor, Adonara, and

5 voc-archief (Dutch East India Company Archives; hereafter voc), Nationaal Archief (National Archives of the Netherlands), The Hague, inv. nr. 1271, Banda, Missive from Gov. Antony Hurt of Banda to Batavia, 18 Sept 1669, 45or; voc inv. nr. 1663, Timor, Missive from Opperhooft en Raad Timor, 8 May 1702, 8. 


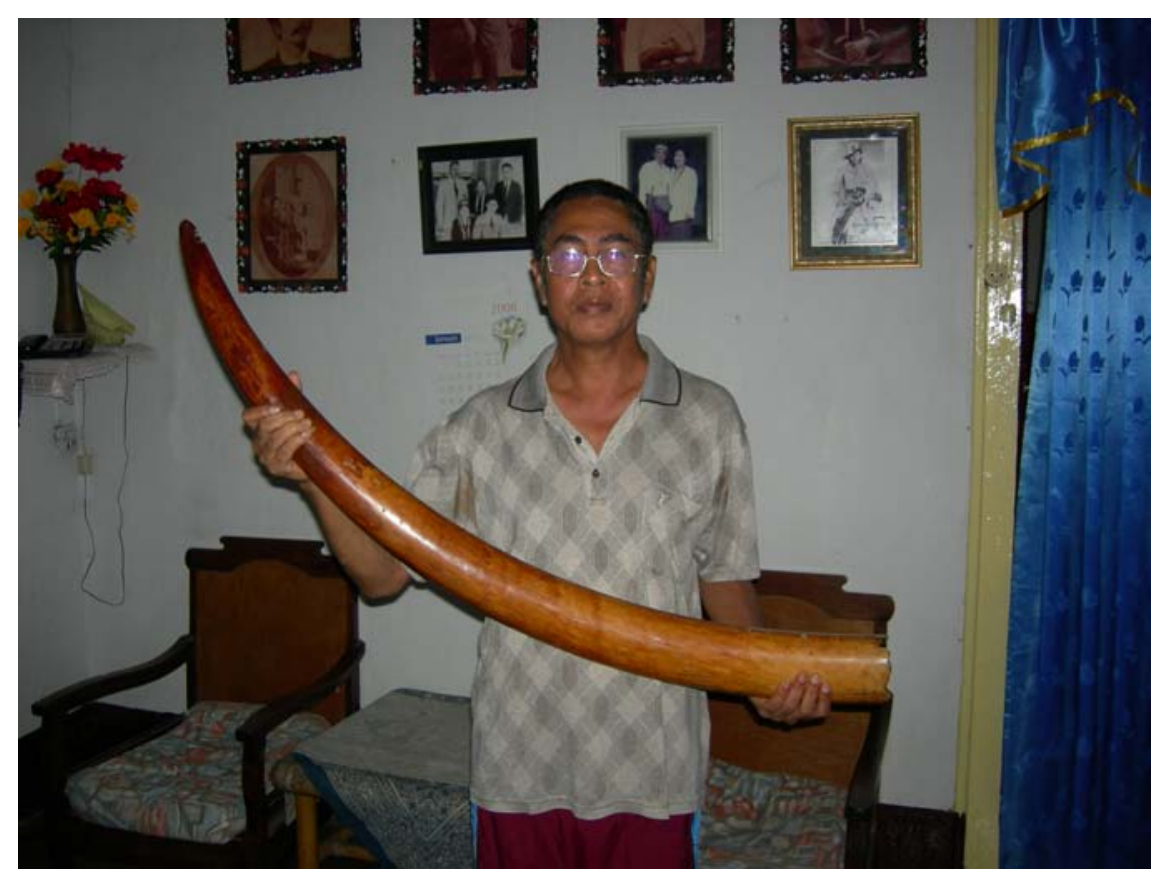

FIGURE 2 Large elephant tusk owned by the Raja Larantuka family PHOTOGRAPH BY AUTHOR

Lembata, as well as among the Sikka in east-central Flores and those in the Tanimbar and Aru archipelagos in southern Maluku, determining the appropriate bridewealth ${ }^{6}$ is still an important objective in marriage negotiations. Elephant tusks traditionally comprised the most valuable of the objects that constituted the bridewealth in these communities. In the past the inability of the groom's family or social group to provide the necessary tusks normally resulted in the annulment of an engagement. For this reason there was a small but reliable demand for tusks, which were exchanged for cloves, nutmeg, mace, and sandalwood. Traders from the western archipelago and Makassar appeared regularly in the main eastern Indonesian markets which were located in the ports of Solor, Alor, and Aru (Rouffaer 1923/24:206; Noorduyn 1983:103-4). The value of Lamaholot women, which reflected the status of the group, was publicly displayed in the number and size of elephant tusks that were presented as

6 Theoretical ideas that underpin the complex concept of 'bridewealth' are succinctly discussed by Duran Bell. In the traditional bridewealth case, he explains, 'one group offers wealth in the form of female reproductivity, whereas the other offers wealth in the form of animal stock, land or some other productive asset' (Bell 1998:192). 
bridewealth (Liliweri 1989:139); hence the higher the status of the group represented by the bride, the greater the quantity and size of the tusks demanded. ${ }^{7}$

Some indication of the material value of the tusks is found in a nineteenthcentury Dutch account, which gives the following equivalences: a large tusk was equal to a slave or a small swivel gun (lela) or a large gong; a middle-sized tusk was equal to two gold plates or two red sarongs or a small gong (Riedel 1886:289). While initially such prices could cause considerable hardship for the groom's family or group, in time their women would receive elephant tusks from their prospective spouses and thus replenish the family's stock for future marriages.

Payment of bridewealth was the primary reason for the trade in elephant tusks, and their essential role in certain societies made them objects of considerable importance in a variety of transactions. Whenever there was warfare among the two major divisions of the Lamaholot, the Paji and the Demon, one of the items used to ransom a prisoner was an elephant tusk (Arndt 2003:294). In an episode from the seventeenth century, peace was finally achieved between the Portuguese and Lamahala, a settlement on the island of Adonara, when it was agreed that Lamahala would present the Portuguese with two slaves and 19 pieces of Indian patola cloth in return for a counter-gift of elephant tusks. The agreement was never enforced because of the failure of the Portuguese to provide the elephant tusks (Coolhaas 1964:683-4). On one occasion the son of the leader (sengaji) of the settlement of Lamakera on Solor Island was seized by the sengaji of Adonara, but he was subsequently released by the payment of a ransom consisting of a piece of patola cloth, ten rix-dollars, a sheep, and an elephant tusk. ${ }^{8}$ Elephant tusks were also levied as fines on vassal areas by the raja (i.e., the sengaji) of Adonara (Barnes 1974:9). So revered were elephant tusks that any transaction involving these objects was marked by some form of commemorative feasting. One particular case was the reconciliation of two feuding families in 1986, which was solemnized by the joining of their surnames and the exchange of elephant tusks (Barnes 1989:540-1).

Because of the importance of whole elephant tusks in bridewealth negotiations in some societies, one anthropologist has suggested that intermarriage between groups which valued different objects could pose problems. She was told that a man from Alor, where the moko, or small bronze drum, is a requisite item in bridewealth, would face difficulties because he had to obtain elephant

7 In one of the villages, a large tusk was considered to be about six feet (depa) in length (Widiyatmika 2007:54).

8 voc, inv. nr. 1663, Timor, Missive from Opperhooft en Raad Timor, 8 May 1702, 8. 
tusks in order to marry a woman from Solor (Rodemeier 1995:439-40). Some believe that the formation of the two federations - the Galiyao Watan Lema (Five Coastal Areas of Galiyao) and the Solor Watan Lema (Five Coastal Areas of Solor) - was to resolve the problem of differing bridewealth requirements between neighbouring communities (Rodemeier 1995:439). The creation of a ritual brotherhood (bela baja), such as that between the two Watan Lema leagues, removed the necessity of paying a bridewealth (Gomang 1993:39, 889). ${ }^{9}$

Elephant tusks were also a valued item in the Tanimbar or Timorlaut islands, where they were given as bridewealth, exchanged for other goods, and served as a form of currency. The Dutch were the major suppliers of elephant tusks to the Tanimbar archipelago in the eighteenth century, and the people on the island of Fordata in the middle of the last century continued to recount stories of obtaining elephant tusks in exchange for amber (Drabbe 1940:139). In the Aru archipelago elephant tusks, copper gongs, porcelain plates, and cloth were exchanged as a sign of friendship. When a person died in Aru, it was important to send the deceased to the other world with his/her worldly possessions, including elephant tusks, which were broken, smashed, or torn as a sign of mourning (Riedel 1886:260, 267, 289). The destruction of the tusk has resonances with the practice in ancient India, where widows on the death of their husbands smashed the ivory bangles presented to them at the time of their engagement or marriage (Chaiklin 2009:8).

In east-central Flores, among the Sikka, elephant tusks were formerly also an important part of objects presented as bridewealth and were obtained mainly from Javanese traders. In addition to traders coming to Ende on the southern coast of Flores to trade elephant tusks, the people of Sikka exchanged products from their interior gardens in the mountains for elephant tusks from Solor. Sikkanese traditions tell of the large quantities of tusks available in Solor to the extent that even the oars of their ships were made of ivory (Kolit 1982:24). The elephant tusk among the Sikka was symbolically a replacement for a woman's power of social reproduction, as well as a symbolic representation of the sovereign authority of the rajadom of Sikka. The raja would present to prospective client chiefs a pair of elephant tusks, known as bala mangung (tusk and mast) or mangung layar (mast and sail), as tokens of alliance and thus

9 The Solor league consisted of the settlements of Lohayong and Lamakera on Solor; and Lamahala, Terong, and Adonara on the island of Adonara. The Galiyao league comprised the settlements of Pandai, Bernusa, and Belagar on Pantar; and Alor and Kui on the island of Alor. The crucial component of bridewealth among the Galiyao was the moko, while among the Solor league members it was the elephant tusk. 
expand his domain. According to Sikka myth, there were some thirty pairs of elephant tusks that accompanied the Sikka rajas from Melaka, thus providing the basis of their sovereign power (Lewis 2010:56fn2, 91, 134, 137, 152-4). Among the Sikka, the elephant tusks symbolized both fertility and royal authority, which are precisely the aspects associated with the other major object of this study: bronze kettledrums.

\section{Bronze Kettledrums as Social Objects in Alor and Pantar}

Bronze and brass kettledrums, known as moko, fulfil the same function in the neighbouring islands of Alor and Pantar as elephant tusks do for the Lamaholot areas, Tanimbar and Aru. The actual moko finds were on the island of Alor, which in earlier centuries was a major redistribution centre for the slave and spice trade in Nusa Tenggara Timur. Dutch seventeenth- century sources explicitly mention that Alor was a well-frequented port for traders from Makassar, ${ }^{10}$ then the most important entrepôt in the whole of eastern Indonesia (Knaap and Sutherland 2004). But as mentioned above, trade to Alor occurred even earlier and folk traditions mention the role of Majapahit in the establishment of some of the clans on the island. In the sixteenth and seventeenth centuries, the Makassarese, Bugis, and Sama Bajau were prominent traders to Alor, and their descendants were also absorbed into the clans in Alor society or formed their own subclans. Again, folk traditions mention these foreign traders as those who would have brought the moko to Alor (Gomang 1993:85-7, 99-100, 107; Nolde 2014:122-207), presumably having purchased these drums in very early times from Chinese or Malay intermediaries with direct links to the original production sites in northern Vietnam or southwest China (Calò 2009:112). So numerous were the moko found on Alor that the island came to be known as 'Alor, Island of a Thousand Moko' (Purna 2009:94).

Bronze kettledrums have been found scattered from southern China to the coast of Papua, and their manufacture may have begun sometime between about 600 to 300 вСE in the workshops of northern Vietnam. This period is known as the Dong Son phase of Vietnamese proto-history, and is characterized by the presence of bronze drums, high-status burials, and iron. In 1902 Franz Heger classified the Southeast Asian and southern Chinese drums, known at the time by region and chronology, into Heger types I-IV. There have been subsequent variations in the classification based on geography, form, decoration,

10 Voc inv. nr. 1663, тім0R, Missive from Opperhooft en Raad Timor, 8 May 1702, 6. 
and (when known) function (Glover 2010:19-20; Bernet Kempers 1988:29-30). Charles Higham's study of bronze cultures in Southeast Asia makes it clear that the Dong Son drums were part of an entire range of bronze objects that signified high status, with the drums being the foremost symbol of a new aristocracy. Finished bronzes, along with other exotic stone and shell objects, provided their owners with high social status and were intended to be displayed; thus they were rarely found in mortuary contexts. To this day, among the highland groups in Vietnam, ownership of bronze drums is the prerogative of high-ranking individuals (Higham 1989:187, 201-2; 1996:134, 327; 2002:175). A similar sentiment is echoed by Ian Glover, who believes that the wide distribution of both bronze drums and urns indicates that they were circulated as prestige goods (Glover 2010:19). The Dong Son culture is seen as moving towards a highly stratified and partly urbanized society, and would have transmitted such ideas along with the drums to societies in other parts of Southeast Asia (Bellwood 1985:269-71; Calò 2009:84).

A recent study by Ambra Calò suggests that there were two separate routes and different chronologies in the distribution of the Dong Son bronze drums from their production sites in northern Vietnam or southwest China. Beginning sometime in the first century $\mathrm{CE}$, traders carried these kettledrums along a route that went from mainland Southeast Asia to the Malay Peninsula and southern Sumatra to Java, but they did not continue eastward as previously believed. According to Calò, a second route was used from a later, single period between the late third to the fifth century CE. It went from the production sites in northern Vietnam and southwest China by sea to northern Borneo, Sulu, and then onward to the Sulawesi and Maluku seas. From these latter seas the drums entered into local trading systems, where their journey continued in the hands of local traders (Calò 2009:111-7), among whom one of the most prominent was the Sama Bajau (Nolde 2014).

Calò's argument is based on a number of shared features among the bronze drums found in eastern Indonesia in the islands of Sangeang, Salayar, Alor, Rote, central, southeast, and southwest Maluku, and northwest Papua, which he categorizes as 'Region Specific Cluster 3 (Rs3)'. Of some 27 of the Rs 3 bronze drums that were known, four were lost or destroyed. Certain noteworthy features are associated with this particular cluster of drums: (1) All are chance finds consisting of only one or a pair of drums, with the exception of Sangeang, which had seven, but none with a context; (2) many were found in situ and were incorporated in adat ceremonies; (3) all contain a unique decorative feature in the lower mantle in the Salayar and one of the Sangeang drums; and (4) all have four frogs or toads cast in relief around the tympanum (Calò 2009:113-5). Some of the drums depict multiple frogs piled one atop the other in copulat- 
ing poses. The manner in which the drum is beaten recalls either the croaking of frogs or the clap of thunder, which precedes the rains. The people in the Sangeang islands believe that if the drums are struck, a rain storm would ensue, and that the three-dimensional frogs placed around the tympanum and the sounds made by the bronze drums possess magical qualities that will bring rains and assure the fertility of the land (Bernet Kempers 1988:21, 67-8, 1778; Calò 2009:121). Some societies distinguish 'male' drums bearing frogs from 'female' drums which do not have frogs, thus clearly associating such drums with fertility (Bernet Kempers 1988:19, 177).

Only the Salayar and the Sangeang drums of the RS3 category have pictorial representations on the lower mantle. The former depicts elephants and horses being led by human figures, and the latter shows elephants and birds interspersed with palm trees. Calò notes that at the centre of the tympanum of all Dong Son bronze drums is a sun/star motif with rays, sometimes interspersed with stylized feather motifs, and that around the sun/star are concentric pictorial bands showing flying birds or 'stylized feathered man' motifs. He argues that such motifs convey the idea of a supernatural world breaching natural categories and enabling transformation from one to the other. In this ritual stance there is also the inference of communication and a relationship with the ancestors, as suggested by the burial context of some of the drum finds (Calò 2009:79, 19-20). The presence of elephants also recalls the association of this animal with Indian and Buddhist kingship, thus combining both the fertility and the status aspect of bronze drums. These small bronze drums, shaped like an hourglass and known as moko, have come to play an important ritual and social role in the islands of Alor and Pantar. These small islands are distinguished by the fact that they are the only archipelagic societies where an essential part of the bridewealth is the moko. A Dutchman in the middle of the nineteenth century described it as a 'kind of brass drum or cymbal, shaped like a spittoon with a cover'. The early moko were of bronze and may have originated in mainland Southeast Asia and arrived along with the Dong Son Heger 1 drums. In the nineteenth century they were supplemented by brass ones, made principally in Gresik in eastern Java and brought by Javanese and Sulawesi traders. Towards the end of that century, a Dutch official observed that the moko were used in Alor and Pantar as an exchange medium by both the people in the mountains and on the coasts and were displayed proudly during special feasts and ceremonies (Bernet Kempers 1988:363-5).

By the early twentieth century there were thousands of moko in these two islands, most of which would have been the brass versions made in Java. Their values thus differed depending on the provenance, the history, the sentimental value, and the reputed spiritual power of the moko. Only the most valuable 


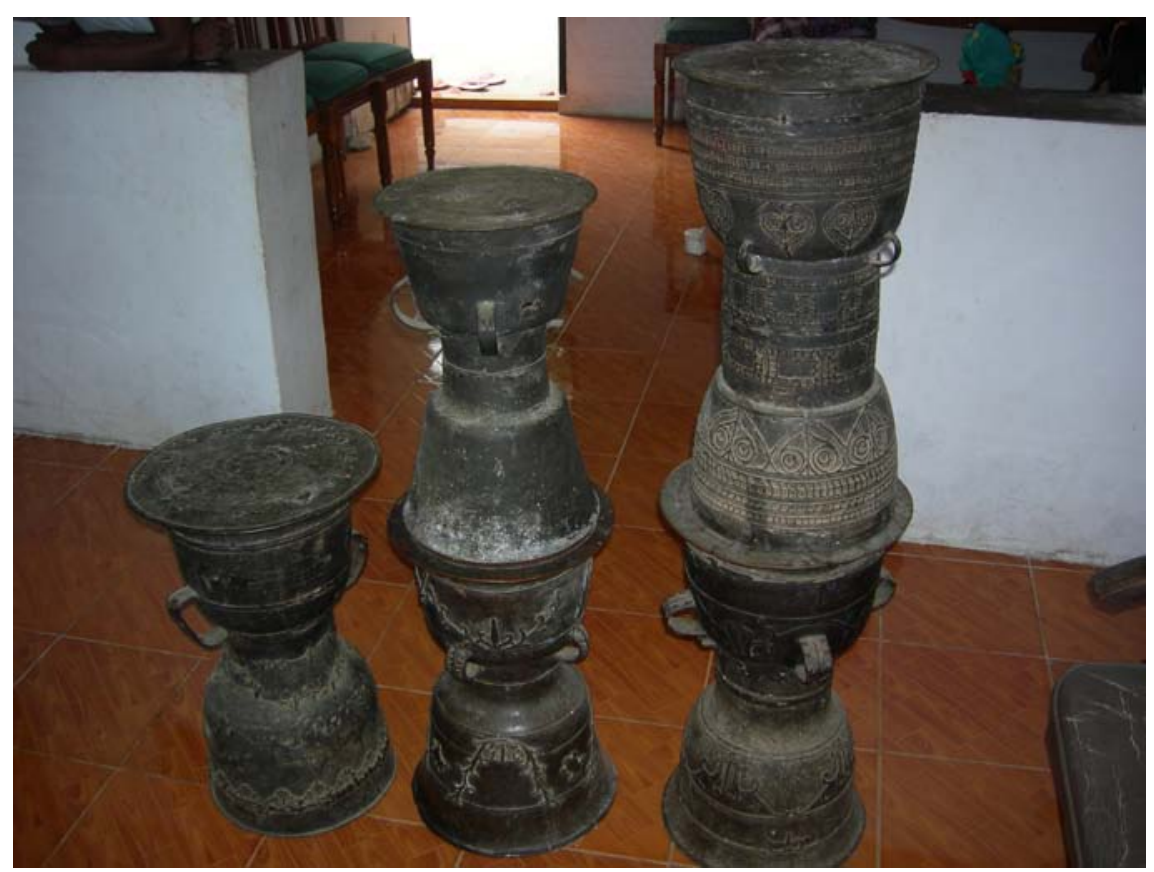

FIGURE 3 Five brass moko baru from Pantar, with a moko placed atop the moko in the centre and the one on the right PHOTOGRAPH BY AUTHOR

were used as bridewealth among the noble families. These factors were allimportant, and so it mattered not that a drum was in poor condition or even in pieces (Bernet Kempers 1988:367-71; Du Bois 1960:515). Cora Du Bois even witnessed a practice in Alor in the 1930s, where the top of the moko was split in two and shared between two parties. On another occasion two men quarrelling over the possession of a moko caused it to break in two. This did not distress the men, who simply took one part of the moko each, thus apparently solving the problem to their satisfaction (Du Bois 1960:489, 515). Moko at the time ranged in price from 1,00o rupiah and upwards for an Itkira moko to 1 rupiah for a Lansingtafa moko. The people were very much aware of the value of the various moko, ${ }^{11}$ which were used for bridewealth, payment of debt, and to purchase pigs for important feasts and shrouds for the deceased. Bridewealth including

11 The worth of a moko differed between groups (suku), as well as between the islands of Alor and Pantar. For example, a moko Malei tana was of very high value in Alor, but of significantly lesser value in Pantar, whereas the moko Pung or Kuang was held in great esteem in Pantar, but not in Alor (Kotten 1995/96:17). 
moko tended to be three times as large as the counter-gifts from the bride's family (Du Bois 1960:23, 85, 442, 481, 491). ${ }^{12}$

There were two distinct types of moko by this time: the moko tana (earth moko) and the moko baru (new moko), though in more recent times a larger number of distinct types were identified by different names. ${ }^{13}$ While the moko tana was more revered, there was also a place for the brass moko baru. According to Bernet Kempers, the moko baru had their own character and were decorated in their own way. They were not, therefore, imitations but constituted their own, distinctive moko that had a special meaning and function for those who possessed them. Some people in central Alor claim to be able to distinguish the moko tana from the moko baru by passing their hands over the drum's surface and then smelling their hands. Apparently, old bronze has a distinctive smell and taste and gives off certain currents that can be detected (Bernet Kempers 1988:370, 376).

Moko were prominently displayed in twentieth-century ceremonies and special feasts, and were played as accompaniment for dances. When distinguished foreign guests arrived, the bronze gongs, drums, and bamboo flutes were played, but not the old moko tana. Because of the cost, the oldest and most valuable moko were usually owned by a family or a village as a whole, and may have been awarded for services rendered to a ruler or a rich merchant. Individuals, even the poor, could own moko, and they hoped in time and in better circumstances to exchange the smaller for the more prestigious larger ones. Since the moko were considered so ritually important, they were kept in the loft in a special room with other valuables where they could be safeguarded until they were required for public display (Bernet Kempers 1988:383; Du Bois 1960:408).

One of the most important functions of the moko is as an essential partial payment of the bridewealth. At least one gong was required for any marriage negotiation, and the proposal of marriage by the groom is often described as the offering of his family's moko. In seeking a suitable partner for his sister, a man from Alor put it simply: 'If my sister wishes, I shall go and ask some man for gongs and moko' (Bernet Kempers 1988:384; Du Bois 1960:515). There appears to have been an interchangeability between moko and women in Alor and Pantar society. In a laira, or traditional poem in the Senaing language, collected by Syarifuddin Gomang, there is mention of the practice of exchanging young, local women for moko brought by foreign traders. In this laira the woman agrees

\footnotetext{
12 Du Bois (1960:85) uses the term 'dowry payments', but she is actually referring to the counter-gifts given by the wife's family to the family of the groom.

13 A long list of named moko can be found in Widiyatmika 2007:96-8.
} 
that a fair exchange would be seven moko for her and patola cloth from India for her brothers. In this transaction, the mutual respect that is engendered through an agreement of the bridewealth between two parties is reaffirmed (Gomang 1993:69).

But perhaps the more significant aspect of the link between women and the moko has to do with fertility. When Cora Du Bois was collecting dreams from the people of Alor in the 1930s, she recorded a woman who dreamed that a distant relative of her husband had given her three large and thirteen small bundles of corn, a gong, and a moko. When she brought them home, her husband told her to put the corn in the house and the gong and moko in the loft. She then told Du Bois that the dream meant that she would have a lot of food that year (Du Bois 1960:400). The fertility imagery is clear in the juxtaposition of maize with the spiritually potent moko and gong.

The link between the moko and fertility is further implied by the alternate name given to the early bronze drums, moko tana (earth kettledrum), because of where they were found. According to one tradition, they were discovered by villagers while hunting in the forest when their dogs began barking at the moko buried in the ground. ${ }^{14}$ Bernet Kempers found it curious that these small bronze drums came to be used as bridewealth in Alor and Pantar. This usage, he believed, was due simply to the fact that they were more portable and therefore could fulfil such a function. Otherwise, he argues, these bronze drums would have been put 'in some suitable place, like the top of a hill, for instance', as was done to the much-larger Heger 1 bronze drums found elsewhere in the archipelago (Bernet Kempers 1988:19, 365, 370). But the function of the moko tana as an essential part of the bridewealth is wholly in keeping with the association of bronze drums with fertility as discussed above.

Further reinforcement of this idea would have been the chance finds of these moko buried in the soil. In 1933 Paul Mus first described a belief system in ancient Champa in southern Vietnam, which venerated the energies of the soil as a deity. Evidence of this deity was made manifest in the form of a stone, a hill or mountain, or a tree-particularly the massive banyan trees-at which place offerings could be made by the community (Mus 1975). In southwest Sulawesi the Bugis and Makassarese venerate a special flat stone in the village, the possik tana (the navel of the earth), which is associated with the soil deity and the coming of the gods from the Upperworld to rule the earth. Offerings

14 This tale recalls the decision by a Malay king to settle in Melaka, when a cornered mouse deer kicks one of the king's hunting dogs. The uncharacteristic behaviour of the mouse deer convinces the king of the spiritual potency of that location, and so he names the city after the tree under which he was standing when that incident occurred (Brown 1952:52). 
are placed on the stone to ensure the fertility of the land, and women who hope to conceive will put an egg on the possik tana (Gibson 2005:176-8). In the same way, the discovery of the moko tana in the ground in Alor may have had similar connotations and hence may have been regarded as the fruit of the earth's fecund womb, as was all natural vegetation. From this belief it was only a small step for the people of Alor and Pantar to venerate the moko as a partial immanence of the soil deity, and hence an appropriate and necessary object to present to a prospective bride and future mother.

\section{Conclusion}

The reason that elephant tusks and bronze (and later brass) kettledrums, or moko, became an especially valued object as bridewealth in certain societies in eastern Indonesia should now be clear. Both objects are extrinsic to the society and difficult to procure - hence their value as a rare, mysterious, and spiritually potent presence. Indian and early mainland Southeast Asian conceptions of elephants and their tusks, and of bronze kettledrums, would have travelled with merchants bringing these items to the east to trade for spices, precious woods, and valuable sea products. A particularly attractive aspect of both the elephant tusk and the moko was their association with rain and fertility. Eastern Flores, the Solor archipelago, Alor, and Pantar are part of Nusa Tenggara Timur (NTT), while Tanimbar and Aru form part of Maluku. As a result of low rainfall, high wind speeds, and intense solar radiation, NTT is the driest part of Indonesia, though southern Maluku also experiences some of this weather pattern. The rain-bearing northwest monsoon winds drop most of their moisture over western Indonesia before reaching NTT, and the dry season is extreme because of the dry, southeast winds and the low topography of many of the islands. It is the strength and duration of these dry trade winds that have had a severe impact on life in the region (Monk, De Fretes and Reksodiharjo-Lilley 1997:69, 71).

Some of the people today continue to speak of the 'hunger season' (musim lapar), when all the leaves have fallen from the trees and the landscape is totally brown from lack of moisture. The people consume all their reserves of rice, plantains, and tubers, while waiting for the rains. Once the rains return and food is again available, the women and children are fed first, and if there is more available then the men eat (Du Bois 1960), a practice which continues today in some areas. ${ }^{15}$ In such dire conditions faced every year by the people,

15 Interviews by author with villagers in NTT in the period February to April 2008. 
rain becomes a precious, life-giving resource. The desire to assure the arrival of rain would have forced the society to seek to placate whatever gods believed to be responsible for this phenomenon. It is very likely that Indian and Southeast Asian legends and beliefs of the rain-producing powers of elephants and bronze drums would have reached these islands through traders. In India the tusk appears to have been singled out as the most sacred part of the elephant, serving as the bridge between the worlds of the sacred and the profane. It is the tusk, therefore, that became the means by which the Lamaholot communities and those of Tanimbar, Aru, and Sikka sought to guarantee favourable rains and assure the fertility of the land. For the people of Alor and Pantar, this function was reserved for the moko, whose sounds when struck summoned the forces that would bring the rains and fertility to the community.

Both the elephant tusk and the moko thus became objects of veneration and were assigned a role as a major gift in bridewealth. Through these sacred objects, the bride was being blessed with fecundity and the promise of abundance for the family. On the island of Salayar, off the southern end of Sulawesi, a Dong Son drum was found with elephant figures and birds interspersed with palm trees depicted in the lower mantle (Calò 2009:7; Bellwood 1985:72 [plate 47]). The depiction of elephants, an animal not known in the area, would have had a purposeful borrowing. As discussed above, scholars have associated bronze kettledrums with rain-making and fertility rites, as well as local authority. Striking evidence of the link between elephants and bronze drums with rain/fertility and authority is the discovery in Java of a water vessel used for religious purposes in the form of an elephant that had been placed in a kettledrum/gong (Gröner and Saller 1999:177; Bernet Kempers 1988:68). In a recent Sikka ceremony the elephant tusk and the moko were viewed as an inseparable pair, with the former being regarded as masculine and the latter as feminine. Their presence together was crucial to the ceremony conducted in the middle of the agricultural fields to assure the fertility of the land (Widiyatmika 2007:95) $\cdot{ }^{16}$ Including the elephant tusk and the moko together in sacred ceremonies or individually in bridewealth negotiations is thus seen as necessary to assure that rains would continue to return every year to relieve the droughtstricken land and bless the community with plenty.

16 While this is a modern observation, the nature of the ceremony itself appears to be traditional. 


\section{References}

\section{Published Sources}

Andaya, Barbara Watson (2006). The flaming womb: Repositioning women in early modern Southeast Asia. Honolulu: University of Hawai'i Press.

Andaya, Leonard Y. (2008). Leaves of the same tree: Trade and ethnicity in the Straits of Melaka. Honolulu: University of Hawai'i Press.

Andaya, Leonard Y. (2011). 'Eastern Indonesia: A study of the intersection of global, regional, and local networks in the "extended" Indian Ocean', in: Stefan HalikowskiSmith (ed.), Reinterpreting Indian Ocean worlds: Essays in honour of Kirti N. Chaudhuri, pp. 107-40. Cambridge: Cambridge Scholars.

Arndt, Paul (2003). Falsafah dan aktivitas hidup manusia di kepulauan Solor. Maumere: Penerebit Puslit Candraditya. [Translation from the 1951 German edition.]

Barnes, R.H. (1974). Kedang: A study of the collective thought of an eastern Indonesian people. Oxford: Clarendon Press.

Barnes, R.H. (1989). 'Méi Nafa, a rite of expiation in Lamalera, Indonesia', Bijdragen tot de Taal-, Land- en Volkenkunde 145:539-47.

Bell, Duran (1998). 'Wealth transfers occasioned by marriage: A comparative reconsideration', in: Thomas Schweizer and Douglas R. White (eds), Kinship, networks, and exchange, pp. 187-209. Cambridge: Cambridge University Press.

Bellwood, Peter (1985). Prehistory of the Indo-Malaysian archipelago. Rev. ed. Honolulu: University of Hawai'i Press.

Bernet Kempers, A.J. (1988). The kettledrums of Southeast Asia. Republished in the Modern Quaternary Research in Southeast Asia 10. Brookfield, vT: A.A. Balkema.

Bougas, WayneKin (1998). 'Bantayan: An early Makassarese kingdom, 1200-1600 A.D.', Archipel 55:83-123.

Brown, C.C. (1952). Sejarah Melayu or Malay annals. Kuala Lumpur: Malaysian Branch of the Royal Asiatic Society.

Bulbeck, F. David and Caldwell, Ian. Land of iron: The historical archaeology of Luwu and the Cenrana valley; results of the Origin of Complex Society in South Sulawesi Project (oxIs). Hull: Centre for South-East Asian Studies, University of Hull, 2000.

Calò, Ambra (2009). The distribution of bronze drums in early Southeast Asia: Trade routes and cultural spheres. Oxford: Archaeopress. [BAR International Series 1913.]

Chaiklin, Martha (2009). 'India in the early modern ivory trade'. Paper presented to the World Economic History Congress, Utrecht, 3-7 August.

Coedès, G. (1968). The Indianized states of Southeast Asia. Honolulu: East-West Center Press.

Coolhaas, W.Ph. (ed.) (1964). Generale missiven van gouverneurs-generaal en raden aan heren XVII der Verenigde Oostindische Compagnie. Vol. 2. 's Gravenhage: Nijhoff. 
Dijk, Wil O. (2006). Seventeenth-century Burma and the Dutch East India Company, 16341680. Singapore: Singapore University Press.

Drabbe, Petrus (1940). Het leven van de Tanimbarees: Ethnografische studie over het Tanembareesche volk. Leiden: Brill.

Du Bois, Cora (1960). The people of Alor: A social-psychological study of an East Indian island. Cambridge: Harvard University Press.

Ellen, Roy (2003). On the edge of the Banda zone. Honolulu: University of Hawai'i Press.

Gibson, Thomas (2005). And the sun pursued the moon: Symbolic knowledge and traditional authority among the Makassar. Honolulu: University of Hawai'i Press.

Glover, Ian C. (2010). 'Bronze drums, urns, and bells in the early metal age of Southeast Asia', in: Louise Allison Cort and Paul Jett (eds), Gods of Angkor: Bronzes from the National Museum of Cambodia. Washington, DC: Arthur M. Sackler Gallery, Smithsonian Institution.

Gomang, Syarifuddin R. (1993). 'The people of Alor and their alliances in eastern Indonesia: A study of political sociology'. [MA thesis, Department of Sociology, Wollongong University.]

Gröner, Karl and Martin Saller (1999). Elephants: A cultural and natural history. Cologne: Könemann.

Hägerdal, Hans (2012). Lords of the land, lords of the sea: Conflict and adaptation in early colonial Timor, 1600-180o. Leiden: KITLV Press.

Higham, Charles (1989). The archaeology of mainland Southeast Asia. Cambridge: Cambridge University Press.

Higham, Charles (1996). The bronze age of Southeast Asia. Cambridge: Cambridge University Press.

Higham, Charles (2002). Early cultures of mainland Southeast Asia. Bangkok: Riverbooks.

Knaap, Gerrit and Heather Sutherland (2004). Monsoon traders: Ships, skippers and commodities in eighteenth-century Makassar. Leiden: KITLV Press.

Kolit, D.K. (1982). Pengaruh Majapahit atas kebudayaan Nusa Tenggara Timur. Kupang: [n.p.].

Kotten, B.K. (ed.) (1995/6). Koleksi moko Alor di Museum Negeri Propinsi Nusa Tenggara Timur. Kupang: Departemen Pendidikan dan Kebudayaan.

Lewis, E. Douglas (2010). The stranger-kings of Sikka. Leiden: KITLV Press.

Liliweri, Alo (ed.) (1989). Inang: Hidup dan bhaktiku. Kupang: Tim Penggerak PKK, Provinsi NTT.

Loubère, Simon de la (1986). The kingdom of Siam. Singapore: Oxford University Press. [Original published in French, 1691.]

Monk, Kathryn A., Yance de Fretes, Gayatri Reksodiharjo-Lilley (1997). The ecology of Nusa Tenggara and Maluku. Hong Kong: Periplus Editions. 
Mus, Paul (1975). India seen from the east: Indian \& indigenous cults in Champa. Victoria, Australia: Centre for Southeast Asian Studies, Monash University. [Monash Papers on Southeast Asia 3.]

Nolde, Lance (2014). Changing tides: A history of power, trade, and transformation among the Sama Bajo sea peoples of eastern Indonesia in the early modern period. $[\mathrm{PhD}$ dissertation, Department of History, University of Hawai'i.]

Noorduyn, J. (1983). 'De handelsrelaties van het Makassaarse rijk volgens de notitie van Cornelis Speelman uit 1670', Nederlandse Historische Bronnen 3, pp. 96-123. Den Haag: Martinus Nijhoff.

Pelras, Christian (1996). The Bugis. Oxford: Blackwell Publishers.

Purna, I. Made (2009). Moko dalam kehidupan masyarakat Alor. Bali: Departemen Kebudayaan dan Pariwisata, Balai Pelestarian Sejarah dan Nilai Traditional Bali, NTB, NTT.

Rahim, Abd. and Ridwan Borahima (eds) (1975). Sejarah kerajaan Tallo' (suatu transkripsi lontara'). Ujung Pandang: Kantor Cabang II, Lembaga Sejarah dan Antropologi.

Riedel, J.G.F. (1886). De sluik- en kroesharige rassen tusschen Selebes en Papua. 's-Gravenhage: Nijhoff.

Ringis, Rita (1996). Elephants of Thailand in myth, art, and reality. Kuala Lumpur: Oxford University Press.

Robson, Stuart (tr. and ed.) (1995). Desawarnana (Nagarakrtagama) by Mpu Prapañca. Leiden: KITLV Press.

Rodemeier, Susanne (1995). 'Local tradition on Alor and Pantar: An attempt at localizing Galiyao', Bijdragen tot de Taal-, Land-en Volkenkunde 151:438-42.

Roever, Arend de (2002). De jacht op sandelhout: De voc en de tweedeling van Timor in de zeventiende eeuw. Zutphen: Walburg Pers.

Rouffaer, G.P. (1923/24). ‘Chronologie der Dominikaner missie op Solor en Flores, vooral Poeloe Ende, ca. 1556-1638 en bibliografie over het Ende-Fort', Nederlandsch-Indië Oud en Nieuw 8:204-22, 256-6o.

Skeat, Walter William and Charles Otto Blagden (1906). Pagan races of the Malay Peninsula. Macmillan: London. Two vols.

Spillett, P.G. (1999). The pre-colonial history of the island of Timor together with some notes on the Makassan influence in the island. Darwin: Museum and Art Gallery of the Northern Territory. Vogel, J.Ph. (1972). Indian serpent-lore: Or, the nāgas in Hindu legend and art. Varanasi: Prithivi Prakashan.

Warren, William (1998). The elephant in Thai life and legend. Bangkok: Monsoon Editions.

Widiyatmika, Munandjar (2007). Kapita selekta muatan lokal Nusa Tenggara Timur. Kupang: Pusat Pengembangan Madrasah, Nusa Tenggara Timur.

Widiyatmika, Munandjar, I. Gede Suratha, and J.A. Frans (1978). Adat istiadat dan 
upacara perkawinan suku Dawan, Sumba dan Lamaholot, daerah Nusa Tenggara Timor. Kupang: Biro Penelitian Universitas Nusa Cendana.

Wolters, O.W. (1967). Early Indonesian commerce. Ithaca: Cornell University Press.

Wolters, O.W. (1970). The fall of Srivijaya in Malay history. Ithaca: Cornell University Press.

Wolters, O.W. (1999). History, culture, and region in Southeast Asian perspectives. Rev. ed. Ithaca: Cornell Southeast Asia Program.

Zimmer, Heinrich (ed. by Joseph Cambell) (1962). Myths and symbols in Indian art and civilization. New York: Harper Torchbooks.

\section{Unpublished Source}

voc-archief, Nationaal Archief, The Hague 